\title{
The Effect of Sample Height on Spray Coverage in Mature Pecan Trees
}

Clive H. Bock, Michael W. Hotchkiss, Ted E. Cottrell, and Bruce W. Wood, Southeastern Fruit \& Tree Nut Research Lab, United States

Department of Agriculture-Agricultural Research Service, Byron, GA 31008

\begin{abstract}
Bock, C. H., Hotchkiss, M. W., Cottrell, T. E., and Wood, B. W. 2015. The effect of sample height on spray coverage in mature pecan trees. Plant Dis. 99:916-925.

Pecan scab (caused by Fusicladium effusum) is the most damaging disease of pecan in the southeastern United States. Large air-blast sprayers for orchards are used to apply fungicide to control the disease but little quantitative information exists on the spray coverage achieved in the canopy of these trees. A series of experiments using water-sensitive spray cards to record spray coverage (percent area) at different heights and locations up to $15 \mathrm{~m}$ in the canopy of pecan trees showed a significantly greater percentage of card area covered at the lowest sample height when compared with the highest sample height. At the lowest height $(5 \mathrm{~m})$, spray coverage on individual cards ranged from 4.7 to $73.5 \%$ and, at the highest sample height $(15 \mathrm{~m})$, spray coverage ranged from 0.02 to $9.5 \%$. In general, there was little significant difference in spray card coverage up to at least $10 \mathrm{~m}$ but, at 12.5 and $15 \mathrm{~m}$, there was significantly less spray coverage compared with the coverage at $5 \mathrm{~m}$. Regression analysis indicated a consistent linear relationship between sample height in the tree

and the percent area covered. When spray cards were positioned at different heights without possible interference from pecan limbs and foliage, similar effects of sample height on spray coverage were noted. Wind speed measurements showed that air movement declined rapidly with distance from the sprayer fan. Whereas, at $2 \mathrm{~m}$ from the fan, wind speeds were approximately $26 \mathrm{~m} \mathrm{~s}^{-1}$, by $10 \mathrm{~m}$, speeds had declined to 2 to $4 \mathrm{~m} \mathrm{~s}^{-1}$. At distances $>12 \mathrm{~m}$, wind speed was approaching ambient air movement of about 1 to $3 \mathrm{~m} \mathrm{~s}^{-1}$. Although aerial application resulted in numerically greater spray coverage at sample heights $>10 \mathrm{~m}$, it was not significant even though a weak linear relationship $\left(R^{2}=0.21\right.$ to 0.25 ) suggested an effect of height. Characterizing and understanding pesticide spray coverage in pecan will allow us to discern limits imposed by existing technology, and provide the basis for improving spray application methods (or tree management) for more efficacious disease control.
\end{abstract}

Pecan scab (caused by Fusicladium effusum G. Winter) is the most destructive disease of pecan (Carya illinoinensis Koch.) in the southeastern United States; it also occurs in other relatively wet locations (e.g., eastern South Africa and southern Brazil) where the crop is grown (Bock 2013; Demaree 1924). On fruit, if infection is early and severe, scab can lead to premature fruit drop (Gottwald and Bertrand 1983, 1988; Sanderlin 1995; Stevenson and Bertrand 2001); with later or less severe disease, loss of yield and quality in harvested fruit will occur (Gottwald and Bertrand 1983; Sanderlin 1995; Stevenson and Bertrand 2001).

The pathogen relies on air and splash dispersal of asexual conidia (Gottwald 1982; Gottwald and Bertrand 1982, 1983; Latham 1982) and, combined with a short life cycle, when conditions are favorable, repeated cycles of infection can result in rapid epidemic development (Gottwald 1985; Stevenson and Bertrand 2001; Turechek and Stevenson 1998).

Older pecan trees in orchards can easily be 20 to $30 \mathrm{~m}$ tall. Studies of the disease distribution in mature pecan trees approximately $16 \mathrm{~m}$ tall, either nontreated or sprayed with fungicides using a groundbased orchard air-blast sprayer, showed that the severity of disease in a tree is generally associated with height (Bock et al. 2013). Nontreated 'Wichita' and 'Desirable' trees had significantly greater disease severity at a height of $5 \mathrm{~m}$ in the canopy, while fungicide-treated trees had significantly less severe disease at $5 \mathrm{~m}$ in the canopy but

Corresponding author: C. H. Bock; E-mail: clive.bock@ars.usda.gov

This article reports the results of research only. Mention of a trademark or proprietary product is solely for the purpose of providing specific information and does not constitute a guarantee or warranty of the product by the United States Department of Agriculture and does not imply its approval to the exclusion of other products that may also be suitable.

Accepted for publication 1 February 2015.

http://dx.doi.org/10.1094/PDIS-11-14-1154-RE

This article is in the public domain and not copyrightable. It may be freely reprinted with customary crediting of the source. The American Phytopathological Society, 2015. similar severities to nontreated trees at heights $>10 \mathrm{~m}$. Another study found more severe disease approximately $5 \mathrm{~m}$ in the canopy of nontreated 'Schley' compared with approximately $10 \mathrm{~m}$ but similar severities at both heights in air-blast sprayer-treated trees and in nontreated trees of Desirable (Bertrand and Brenneman 2001). Further recent data also indicate that more severe disease is most often found in fungicidetreated pecan tree canopies on both fruit and foliage at heights $>10 \mathrm{~m}$ compared with lower in the canopy, where the fungicide is presumably more efficacious (C. H. Bock, M. W. Hotchkiss, and B. W. Wood, unpublished data). Although aerial application can help control disease in the upper canopy of tall trees, it is not considered a substitute for groundbased air-blast sprays (Bertrand and Brenneman 2001). Understanding fungicide coverage in tall trees is vital to ensure and improve delivery of ground-based fungicide sprays more effectively throughout the canopy at all heights in tall trees and, thus, maximize disease control (air-blast sprays are the most widely used application method in pecan orchards).

Apart from issues of disease control, a further consideration regarding fungicide coverage is the potential to select for fungicide resistance (Isakeit 2009; Reynolds et al. 1997; Stevenson 1999; Stevenson et al. 2004). Both protectant and systemic fungicides are available to manage the disease (Brenneman et al. 2014), and uniform fungicide coverage improves disease control and also reduces the risk of fungicide resistance developing. Clearly understanding limitations in spray coverage will help in developing methods to more comprehensively and effectively ensure that the tree is optimally protected.

Air-blast sprayers rely on generation of fast-moving air by axial fans to transport the droplets from the sprayer nozzles to the target plant surface, and have been widely used in orchards and vineyards for the last 50 years (Fox et al. 2008). The air flow from these sprayers tends to decline rapidly with distance from the outlet (Fox et al. 1992) and thus, to some degree, must dictate the effective distance to which spray can be transported. In addition, spray volume will become increasingly diffuse with increasing distance from the nozzles as it spreads through an increasing volume of air. Several methods are routinely used to calibrate these sprayers or test and characterize their spray coverage distribution, including the use of spray cards (Banaj et al. 2010; Fox et al. 2003; Salyani and Fox 1999; Sumner 2004; Syngenta 2002), colorimetric water-sensitive 
string (Salyani et al. 2006; Sumner 2004), patternators of various sophistication (Gil et al. 2013; Pergher 2004), and metal tracers (Herrington et al. 1981; Reilly et al. 2007). With spray cards, although droplet count can be measured at lower coverage, overloading generally makes the measure of percent area covered more accurate to estimate (Fox et al. 2003; Panneton 2002; Salyani et al. 2013) and is an important component of pesticide coverage. The use of air-blast sprayers in tree crops has been studied fairly extensively in smaller orchard crops (for example, apple and citrus) and in vineyards (Banaj et al. 2010; Celen et al. 2008; Herrington et al. 1981; Holownicki et al. 2000; Pergher 2004; Randall 1971; Salyani and Hoffmann 1996; Travis et al. 1987a,b) but less so in large tree crops such as pecan.

Three studies have been reported in pecan to investigate air-blast sprayer spray coverage. The first used water-sensitive cotton string placed at heights above 16 to $18 \mathrm{~m}$ trees and water-sensitive cards up to $15 \mathrm{~m}$ to determine spray deposition in relation to height (Sumner 2004), and a second used a metal tracer system to relate spray coverage in 21 - to $25-\mathrm{m}$ tall trees to sample height, and also investigated volume and speed as components of spray coverage (Reilly et al. 2007). In the third experiment, Bock et al. (2013) also used tracers to study deposition with sample height in tree canopies using an air-blast sprayer. However, although informative in terms of total active ingredient recovered, using a tracer as a surrogate for an active ingredient does not give a direct, clear indication of the area covered by the fungicide (droplets per square centimeter or percent area covered), which are important components of fungicide efficacy, particularly for protectant fungicides. Generally, droplet number for fungicides (protectant or systemic) should not be $<50$ to $70 \mathrm{~cm}^{-2}$ (Syngenta 2002), and droplet volume median diameter for applied fungicide should be 226 to $325 \mu \mathrm{m}$ (Hipkins and Grisso 2009). Nonetheless, all three studies (Bock et al. 2013; Reilly et al. 2007; Sumner 2004) found a decline in percent area with spray coverage or tracer with increasing height when applied using an air-blast sprayer (the Reilly et al. work also studied deposition from aerial application and found that deposition was numerically greatest in the upper canopy compared with the lower canopy). A single study on spray deposition and consequent blight control by air-blast or helicopter-applied spray in walnut trees found good coverage up to approximately $10 \mathrm{~m}$ early in the season but, as the canopy filled, a decline in coverage with increasing height to $10 \mathrm{~m}$ was noted (Olson et al. 1984). Helicopter application showed the opposite trend. These studies have provided some useful descriptive information but provided no or limited statistical analysis of the relationship between height and spray coverage; nor did they establish significant differences in spray coverage at different heights sampled in the canopy. Thus, a need exists to put analysis of spray distribution in mature pecan trees on a more quantitative footing.

The objective of this study was to (i) quantitatively characterize the distribution and relationship of spray coverage with sample height in tall pecan trees, (ii) characterize the air flow from the air-blast sprayers in relation to distance and height as produced by powerful orchard sprayers typically used to spray pecan trees, and (iii) obtain some preliminary data on deposition of aerially applied spray in the middle to lower canopy of tall pecan trees.

\section{Materials and Methods}

Measuring spray coverage. Spray coverage was measured using water-sensitive paper cards ( 52 by $76 \mathrm{~mm}$; Syngenta, Greensboro, NC) following defined instructions (Syngenta 2002). The digital image analysis program Assess V2.0 (Lamari 2002) was used to measure the percent area covered with spray on each card and to count the number of droplets. Digital image analysis has been used to measure area of spray cards covered and found to be a reliable measurement (Fox et al. 2003; Panneton 2002; Salyani et al. 2013); particularly when compared with droplet counts measured by image analysis. Inevitably, due to inter- and intracard variability, spray bleed in the cards, and slight differences in pixel characteristics (color, hue, intensity, and so on), there was some subjectivity in determining margins of sprayed areas. These differences also precluded automating the measurement process, which was done on a card-by-card basis. However, any error in delineation of sprayed areas was small and is not considered of significance due to the magnitude of the treatment effects observed in this study. Two individuals made the measurements on the cards, utilizing the various tools in Assess to maximize accuracy.

Test trees and sample supports. Both ground-applied and aerialapplied spraying methods were tested independently.

Ground applied sprays. Two methods were used to explore spray coverage from ground-based rigs. First, an orchard of 'Moneymaker' trees (85+ years old) located at the United States Department of Agriculture-Agricultural Research Service (USDA-ARS) Southeastern Fruit and Tree Nut Research Laboratory (SEFTNRL) in Peach County, GA was used to characterize spray coverage in trees. The USDA-ARS laboratory is located at latitude $+32^{\circ} 39^{\prime} 54^{\prime \prime} \mathrm{N}$, longitude $+83^{\circ} 44^{\prime} 31^{\prime \prime} \mathrm{W}$, with an elevation of approximately $156 \mathrm{~m}$, an approximately 240-day freeze-free growing period, and annual precipitation of approximately $118 \mathrm{~cm}$. The site has Faceville sandy loam soils (FoA; fine, Kaolintic, thermic Typic Kandiudult soil). Trees were $24 \mathrm{~m}$ tall, spaced at 12 by $17 \mathrm{~m}$, and managed for nutrient elements and pests according to recommendations for commercial orchards (Wells 2007). The trees chosen had full canopies with balanced branching. There were no large gaps in the canopies of these trees and no obvious large, horizontal limbs that would impede spray movement through the canopy. Individual spray cards were stapled by their edge to the upper surface of individual leaves on terminals (marked with fluorescent flagging tape to aid spotting the location of the card). The cards were stapled to leaves in a manner to mimic how a pecan leaf typically hangs in the canopy at heights of 5, 7.5, $10,12.5$, and $15 \mathrm{~m}$ following a transect up the row side of the tree adjacent to the next row. One set of sample cards was stapled to leaves on terminals on the outer canopy of the tree, and a second set was stapled to leaves on terminals in the inner canopy close to the main trunk of the tree. Cards were placed in the tree with use of a hydraulic lift (JLG Industries Inc., McConnelsburg, PA). The height at which to place cards was determined using an Opti-Logic Laser Rangefinder (Opti-Logic, Tullahoma, TN). The maximum sample height for card placement was dictated by the limits of the hydraulic lift (for some experiments, a JLG hydraulic lift with capacity to reach $20 \mathrm{~m}$ was available). Experiments were done three times: 28 September (afternoon to evening [PM]) and 17 October 2012 (morning $[\mathrm{AM}]$ and $\mathrm{PM})$, with three replicate trees used on each occasion. In addition to these three experiments, spray cards were again placed in the same trees and attached to the same terminals of the outer canopy on 10 April 2013 (one experiment AM, repeated PM) when trees were leafless, and sprayed using an air-blast sprayer. Second, spray coverage at different heights in the absence of any branches or foliage to impede spray movement was explored. Helium-filled balloons attached to a string which was secured to the ground were used to support platforms at specific heights onto which water-sensitive cards were stapled by their edge. One set of the water-sensitive cards was stapled to the upper surface of the platform and a second set was stapled to the lower surface of the platform. The platform sample heights were 5, 10, 15, and $20 \mathrm{~m}$ on 28 September 2012 (PM), and 5, $10,15,20$, and $25 \mathrm{~m}$ on 17 October 2012 (AM and PM). The location of the helium-filled balloons was in the same 'Moneymaker' orchard described above but balloons were situated in a row where missing trees provided a location free of canopy obstruction. There were three replicate helium-balloon-supported platform systems on each experiment date. All replicate trees and helium-balloon-supported platforms were sprayed within a few minutes of each other, ensuring similar weather conditions on that day.

Spray (in these cases, water) was applied using a Durand-Wayland 3210A 3790 L orchard sprayer powered by a 325-hp engine (DurandWayland Inc., LaGrange, GA). The sprayer was operated at $3.22 \mathrm{~km} \mathrm{~h}^{-1}$ and calibrated for 940 liters $\mathrm{ha}^{-1}$ at $10.3 \mathrm{bar}\left(1.03 \times 10^{6} \mathrm{Pascal}\right)$. The sprayer nozzles were adjusted appropriately for spraying mature pecan trees. All nozzles in the manifold were fitted with a number 25 ceramic swirl plate (Spraying Systems, Wheaton, IL). Nozzle disc numbers were as follows from sprayer nozzle position 1 (lowest) to sprayer nozzle position 13 (highest) for the front and rear sprayer racks $(\mathrm{X}=$ blank). For the front rack sprayer, nozzle positions 1 to 
$7=$ disc number 2 , position $8=$ disc number 3 , position $9=$ disc number 4 , and positions 10 to $13=$ disc number 6 . For the rear rack sprayer nozzle, positions 1 to $2=X$, positions 3 to $7=$ disc number 2 , position $8=$ disc number 3 , position $9=$ disc number 4 , and positions 10 to $13=$ disc number 6 . Nozzles were positioned to spray two-thirds to three-quarters of the spray to the upper half of the tree and onethird to one-quarter of the spray to the lower half of the trees (Sumner 2005). The sprayer was driven midrow past the tree or heliumballoon-suspended platforms using a single-sided spray. A single pass was made. Cards were allowed to dry in the canopy prior to collection.

For aerial applications. Two adjacent rows of trees in the orchard described above were selected and typical trees in these rows were chosen for card placement. Due to height limitations of the hydraulic lifts, it was not possible to get cards to the very top of these trees. The experiment was done twice: once on 21 June 2012 (AM), when cards were stapled to leaves in the outer canopy at $0,5,7.5,10,12.5$, and $15 \mathrm{~m}$; and again on 5 July 2012, when cards were placed at $0,5,10,15$, and $20 \mathrm{~m}$ (a hydraulic lift with capacity to reach $20 \mathrm{~m}$ was available for the second experiment). The equipment used for the aerial application was an Ayers Thrush (Thrush Aircraft, Albany, GA) fitted with 32 adjustable Cooper-Pegler nozzles operated at 3.1 to 3.4 bar (3.1 to $3.4 \times 10^{5}$ Pascal), calibrated to deliver 74 to 94 liters ha ${ }^{-1}$, flown at $225 \mathrm{kph}$, and operated at 2 to $3 \mathrm{~m}$ above the tree canopy.

Measuring wind speed generated by an air-blast sprayer. To assess the characteristics of wind with height and distance from an orchard air-blast sprayer, the air-blast sprayer described above was positioned in an open area and two different sets of experiments were performed. (i) The sprayer was kept stationary but otherwise operated as specified above and wind speeds were recorded at different distances and heights from the sprayer as follows. A wind sonic anemometer (Gill Instruments, Lymington, Hampshire, UK) was secured to the railing of a hydraulic lift operated by ground control. A string attached to the railing at the point where the sonic anemometer was secured was marked at 1-m intervals (allowing anemometer height to be determined from the ground) to ensure that wind speeds could be measured at each height-distance cross point in the twodimensional matrix of distance $(1.5,5,10,12.5$, and $15 \mathrm{~m})$ and height $(2,6$, and $12 \mathrm{~m})$ from the air-blast sprayer. The wind speed data were recorded for $60 \mathrm{~s}$ at each of the 15 locations, and logged to a Campbell CR 3000 data logger (Campbell Scientific, Logan, UT). The experiment was performed on 20 and 26 November 2012. (ii) The sprayer was operated as described above and driven past the anemometer (set to record wind speed every $0.01 \mathrm{~s}$ ) to record the pulse characteristics of wind speed experienced as the sprayer drove by. This was measured at $6 \mathrm{~m}$ above and $2 \mathrm{~m}$ distant from the fan, approximately representing the low to midcanopy region of a mature pecan tree. The standard deviation of the wind speed was calculated. The experiment was performed three times between 4 and 5 PM on 26 November 2012.

Weather conditions. Weather conditions (temperature, relative humidity, wind speed and direction, and rainfall) were recorded at $15 \mathrm{~min}$ intervals over a $2 \mathrm{~h}$ period of each spray experiment using the weather station located at the USDA-ARS-SEFTNRL $\left(+32^{\circ} 39^{\prime} 54^{\prime \prime} \mathrm{N}\right.$, longitude $\left.+83^{\circ} 44^{\prime} 31^{\prime \prime} \mathrm{W}\right)$, which is part of the Georgia Automated Environmental Monitoring Network (www.griffin.uga.edu?aemn/cgi-bin/AEMN.pl?site=GABY). The mean weather conditions for each experiment are shown in Table 1.

Data analysis. Droplet count could not be used in analysis due to coalescence of droplets on many of the cards at higher percent area coverages, precluding accurate counts. General linear modeling analysis was used to determine whether there were significant differences between the percent spray coverage at each height either in the trees (with or without foliage) or on the platforms suspended by the heliumfilled balloons. Due to heterogeneity of variance, data were square root transformed prior to analysis. Transformation improved residual spread and data were normally distributed. Consequently, backtransformed data are presented with back-transformed 95\% confidence intervals, with mean separation done using Tukey's honestly significant difference test based on the transformed data. In experiments with more than one main effect (sample height, card position, or orientation), the interactions were analyzed as well. Linear regression analysis was used to explore the relationship between spray droplet count per square centimeter and percent area of the spray card covered for both the ground-applied air-blast sprayer and aerially applied results up to 3 droplets $\mathrm{cm}^{-2}$ (the maximum collected by spray cards in the tree canopy exposed to aerially applied spray). For the aerial application on 21 June 2012, there were two spray cards with high coverage at low sample heights, and these were omitted from the analysis, although they are indicated in the results. The position of these two cards presumably resulted in substantially more exposure. The statistical analysis software SAS (V9.3; SAS Institute, Inc., Cary, NC) was used in all analyses.

\section{Results}

Spray coverage from an orchard air-blast sprayer. There was a linear relationship between the spray droplet count per card and the percent area of spray card covered up to approximately $25 \%$ area (Fig. 1). However, on cards with spray covering $>25 \%$, there was a decline in the number of droplets counted by image analysis as the droplets coalesced and it was impossible to tell the true number of droplets. As card area covered approached $100 \%$ (i.e., the whole card being uniformly blue), the droplet count fell to one or just a few droplets counted. Thus, all analyses were based on the percent card area covered, rather than droplet counts.

In trees, the numerically greatest overall mean spray coverage occurred with the 17 October AM sample (23.7\% area sprayed) compared with that on 17 October PM (17.0\% area sprayed) or 28 September PM (9.9\% area sprayed). In all three experiments in trees, there was a significantly greater percentage of card area covered at the lower sample heights when compared with the higher sample heights (Fig. 2A-C). Only for the 17 October PM sample was there a significant height-position interaction. There was no position or other height-position interaction in any of the three experiments. There was variability between and within individual experiments

Table 1. Weather data recorded at the United States Department of Agriculture-Agricultural Research Service Southeastern Fruit \& Tree Nut Research Lab at Byron, GA, during each of the sampling periods ${ }^{\mathrm{a}}$

\begin{tabular}{|c|c|c|c|c|c|c|c|c|}
\hline Date & $\begin{array}{l}\text { Time period } \\
\text { (hh:min) }\end{array}$ & $\begin{array}{c}\text { Temperature } \\
\left({ }^{\circ} \mathbf{C}\right)\end{array}$ & $\begin{array}{c}\text { Humidity } \\
(\%)\end{array}$ & $\begin{array}{c}\text { Wind speed } \\
\left(\mathrm{m} \mathrm{s}^{-1}\right)(\mathbf{S D})^{\mathbf{b}}\end{array}$ & $\begin{array}{c}\text { Direction } \\
\left({ }^{\circ}\right)\end{array}$ & $\begin{array}{c}\text { Rainfall } \\
\text { (mm) }\end{array}$ & $\begin{array}{c}\text { Vapor pressure } \\
\text { deficit (KPa) }\end{array}$ & Conditions \\
\hline 21 June 2012 & $10: 00-12: 00$ & 27.2 & 59.9 & $1.84(0.204)$ & 71.7 & 0 & 1.430 & Partly cloudy \\
\hline 5 July 2012 & $10: 00-12: 00$ & 30.3 & 61.3 & $2.12(0.381)$ & 42.7 & 0 & 1.641 & Clear \\
\hline 28 September 2012 PM & $16: 00-18: 00$ & 27.2 & 59.9 & $1.67(0.808)$ & 30.8 & 0 & 1.430 & Partly cloudy \\
\hline 17 October $2012 \mathrm{AM}$ & $10: 00-12: 00$ & 21.1 & 54.3 & $2.57(0.208)$ & 30.4 & 0 & 1.136 & Clear \\
\hline 17 October 2012 PM & $15: 00-17: 00$ & 24.3 & 34.1 & $2.65(0.148)$ & 25.4 & 0 & 1.965 & Clear \\
\hline 21 November 2012 PM & $15: 00-17: 00$ & 20.5 & 37.5 & $2.00(0.203)$ & 43.8 & 0 & 1.462 & Clear \\
\hline 26 November 2012 PM & $15: 00-17: 00$ & 19.5 & 15.7 & $1.93(0.318)$ & 37.4 & 0 & 1.851 & Clear \\
\hline 13 April 2013 AM & $10: 00-12: 00$ & 24.4 & 52.3 & $2.68(0.251)$ & 26.1 & 0 & 1.422 & Clear \\
\hline 13 April 2013 PM & $15: 00-17: 00$ & 28.3 & 36.1 & $2.68(0.243)$ & 23.6 & 0 & 2.414 & Scattered cloud \\
\hline
\end{tabular}

a Data are 15 min samples averaged over the 2-h experiment period.

b $\mathrm{SD}=$ standard deviation. 
at each height. At the lowest height $(5 \mathrm{~m})$, spray coverage on individual cards ranged from 4.7 to $73.5 \%$ and, at the highest sample height $(15 \mathrm{~m})$, spray coverage ranged from 0.02 to $9.5 \%$. In general, there was little significant difference in spray card coverage up to $10 \mathrm{~m}$, although there were exceptions. However, most often, there was significantly less spray coverage at 12.5 and $15 \mathrm{~m}$ compared with the coverage at $5 \mathrm{~m}$. Exact position and aspect of spray cards on the leaf attached to a specific terminal could dramatically influence the amount of spray collected, as would be true for leaves as well.

The regression analysis showed a consistent linear relationship between sample height in the tree and the percent area covered for both the inner and outer canopy sample positions (Fig. 2D-F, regression statistics in Table 2A). For all experiments and for all sample positions (inner or outer canopy), the analysis showed that there was a decline in the area covered by spray on the spray cards with sample height in the tree, although there was some variability among experiments in the percent areas covered at specific heights.

Dormant, leafless trees showed effects of sample height on the percent card area covered by spray at different heights in the canopy similar to effects on trees with foliage although, overall, the mean spray coverage was greater (34.3 and $32.6 \%$ of spray card area covered, respectively, in the two experiments on leafless trees) compared with the trees with foliage (see above). However, in the first experiment (10 April 2013 [AM]), although there was no significant difference among sample heights, there was a numerically lower percentage of card area covered by spray at greater sample heights in the tree canopy (Fig. 3A and B). In the second experiment (10 April 2013 $[\mathrm{PM}])$, there was significantly less card area covered with spray at greater sample heights, the trend similar to that seen in trees with foliage. Variability in spray coverage on cards was substantial in these experiments at a given height. Thus, at $5 \mathrm{~m}$, spray coverage on individual cards ranged from 4.8 to $99.7 \%$ and, at $15 \mathrm{~m}$, spray coverage ranged from 0.3 to $11.6 \%$. Linear regression analysis confirmed a reduction in percent area covered with increasing height in the canopy of leafless trees (Fig. 3C and D).

On the cards attached to platforms, supported at different heights by helium-filled balloons, there was a numerically similar mean spray coverage for 28 September PM and 17 October AM and PM (24.3, 25.8, and $23.2 \%$, respectively). In all three experiments, there was a significantly greater percentage of card area covered at the lowest sample height for cards, upper and lower orientation, on the platform when compared with the highest sample height (Fig. 4A-C). The effect of height was significant for all three experiments but orientation was significant only for 28 September PM and 17 October $\mathrm{PM}$. There was no significant height-orientation interaction. The percent spray coverage on cards was statistically the same to a sample height of $10 \mathrm{~m}$ in all three experiments. At sample heights $>10 \mathrm{~m}$, coverage was often significantly less than that at $5 \mathrm{~m}$, and invariably less at sample heights of 20 and $25 \mathrm{~m}$ compared with $5 \mathrm{~m}$.

The regression analysis showed a consistent linear relationship between height of the cards and the percent area covered for both the upper and lower orientations (Fig. 4D-F, regression statistics in Table 2B). For all experiments, and for all sample orientations (upper or lower) the analysis showed that there was a decline in the card area covered by spray with sample height in the tree, although there was some variability among experiments in the percent areas covered at specific heights.

The overall spray coverage based on the combined regression solutions from the separate experiments on trees and those supporting cards by helium-filled balloons suggests differences due to the presence of the tree canopy or the method of spray card attachment (Fig. $5 \mathrm{~A}$ and $\mathrm{B})$. Whereas the regression solutions for spray coverage of cards in trees with foliage tended to intersect the $\mathrm{x}$-axis (sample height) at approximately $15 \mathrm{~m}$, the regression solutions for cards in those trees with no foliage intersected the $\mathrm{x}$-axis between 15 and

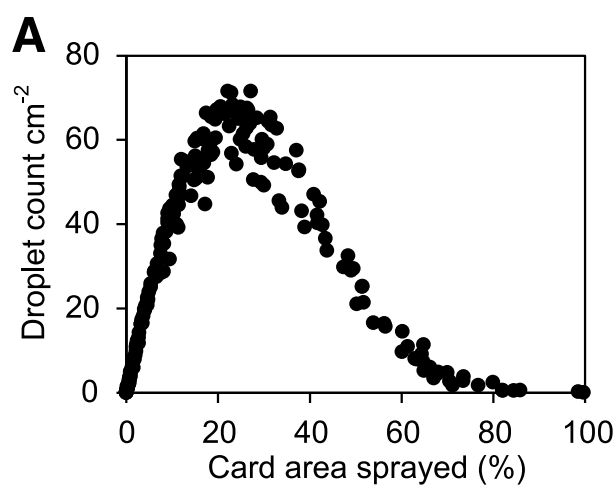

B
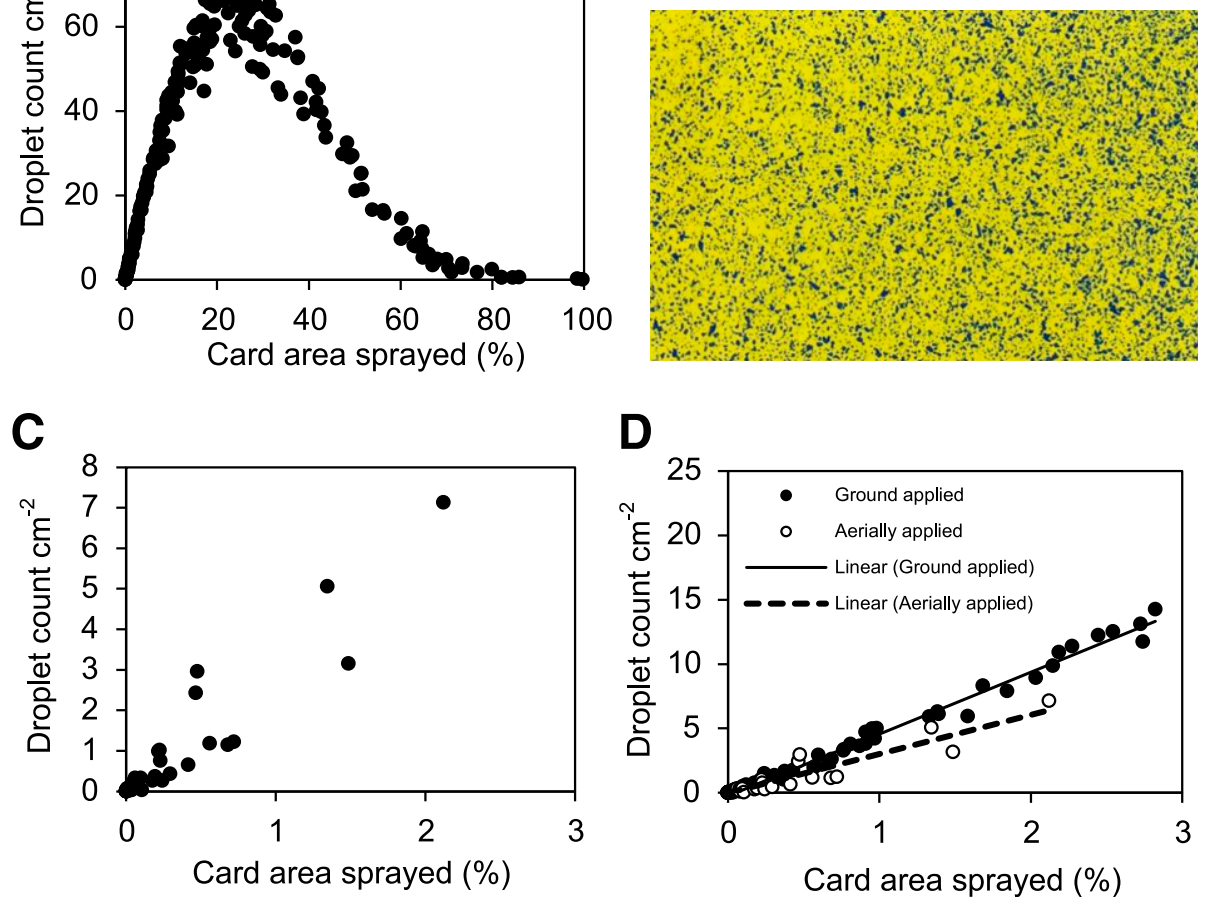

Fig. 1. A, Association between spray droplet count per square centimeter and the percent card area covered by spray droplets as measured using digital image analysis for all airblast sprayer experiments. B, Typical card at the threshold of the ability of the image analysis program to differentiate separate droplets (approximately $20 \%$ card area sprayed; with this card, the image analysis program measured $18.5 \%$ area covered in spray and counted 66 droplets $\mathrm{cm}^{-2}$ ). C, Association between spray droplet count per square centimeter and the percent card area covered by spray droplets as measured using digital image analysis for all aerial application experiments. D, Linear relationship between droplet count and percent card area sprayed up to 3 droplets $\mathrm{cm}^{-2}$ for air-blast sprayer-applied spray $\left(F\right.$ value $=4,050, P$ value $\left.<0.0001, a=-0.25, b=4.81, R^{2}=0.99\right)$ and for aerially applied spray $\left(F\right.$ value $=441, P$ value $\left.<0.0001, a=-0.02, b=3.04, R^{2}=0.89\right)$. 
$20 \mathrm{~m}$ (and tended to have a greater proportion of the card area covered in spray), and the regression solutions for the cards supported by helium-filled balloons tended to intersect the $\mathrm{x}$-axis between 20 and $25 \mathrm{~m}$ (and those cards on the lower-facing side of the platform tended to have a greater proportion of the card area covered in spray). Perhaps the presence of a leafy canopy and branches impeded vertical spray penetration in trees. Furthermore, the regression solutions for spray coverage of cards situated in the inner or outer tree canopies were not clearly grouped whereas, for the cards supported by heliumfilled balloons, card orientation resulted in differences. Those cards attached to the lower side of the platforms most often received more spray compared with those located on the upper side of the platforms.

Wind speeds associated with an air-blast sprayer. Wind speed declined rapidly from the fan with both distance and height (Fig. 6).
The heat map shows that, at $2 \mathrm{~m}$ above the fan, wind speeds had dropped to approximately $26 \mathrm{~m} \mathrm{~s}^{-1}$ and, by $6 \mathrm{~m}$, wind speeds were approximately $10 \mathrm{~m} \mathrm{~s}^{-1}$. By $10 \mathrm{~m}$, wind speed had declined to 2 to $4 \mathrm{~m} \mathrm{~s}^{-1}$ and, at $>12 \mathrm{~m}$, the wind speed was approaching ambient air movement of approximately $1 \mathrm{~m} \mathrm{~s}^{-1}$. When moving at $3.22 \mathrm{~km} \mathrm{~h}^{-1}$, the wind generated by the air-blast sprayer was experienced for only a few seconds, although there was a slight shoulder of increasing wind speed followed by a dramatic peak and sharp decline as the sprayer moved past (Fig. 7). The peak in wind speed was approximately what would be expected at $6 \mathrm{~m}$ of horizontal distance and $3 \mathrm{~m}$ of vertical distance from the wind heat map (Fig. 6).

Aerially applied spray deposition in the mid and lower canopy. Although there tended to be numerically greater spray coverage in these trees above $10 \mathrm{~m}$, there was no significant difference in spray
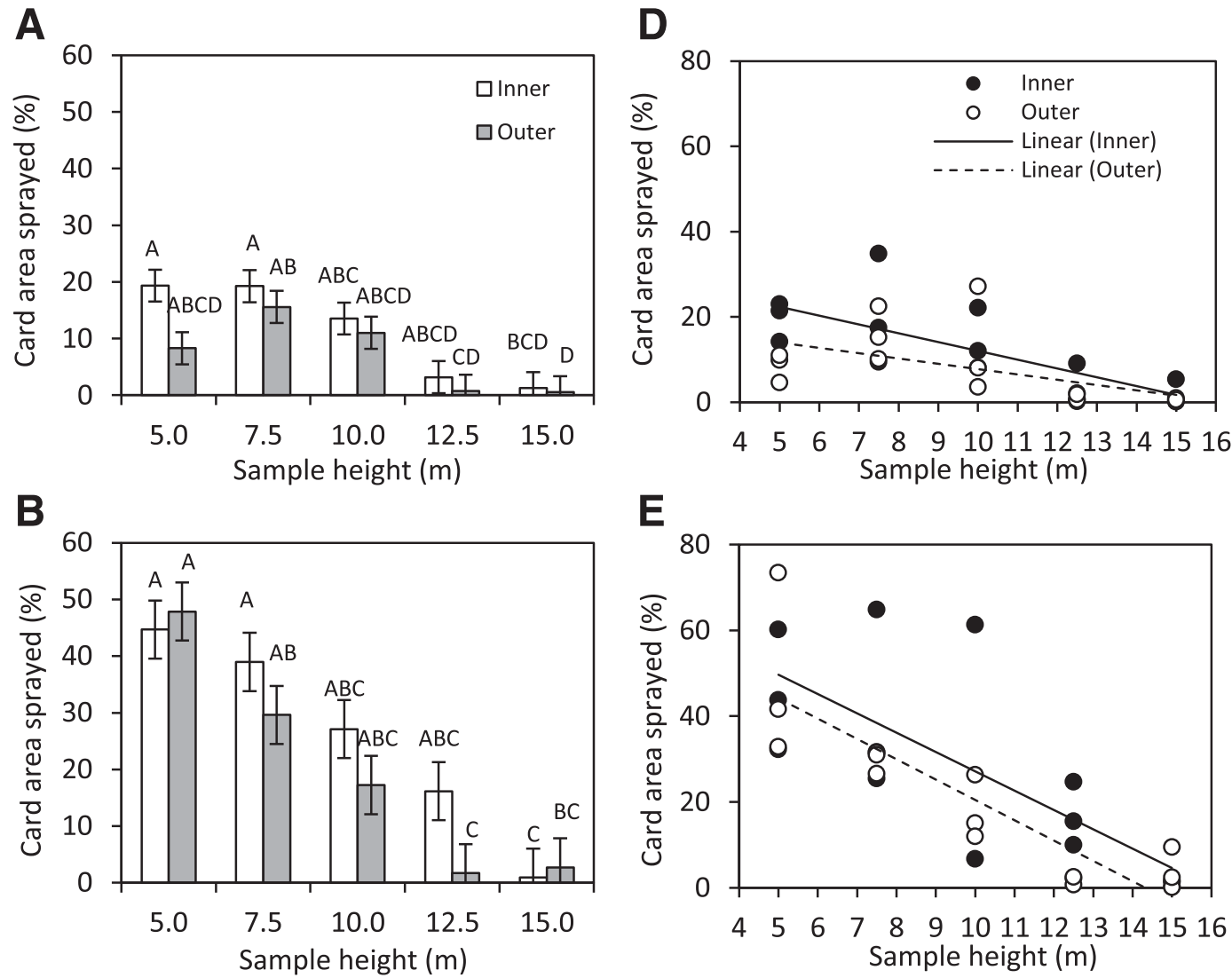

E
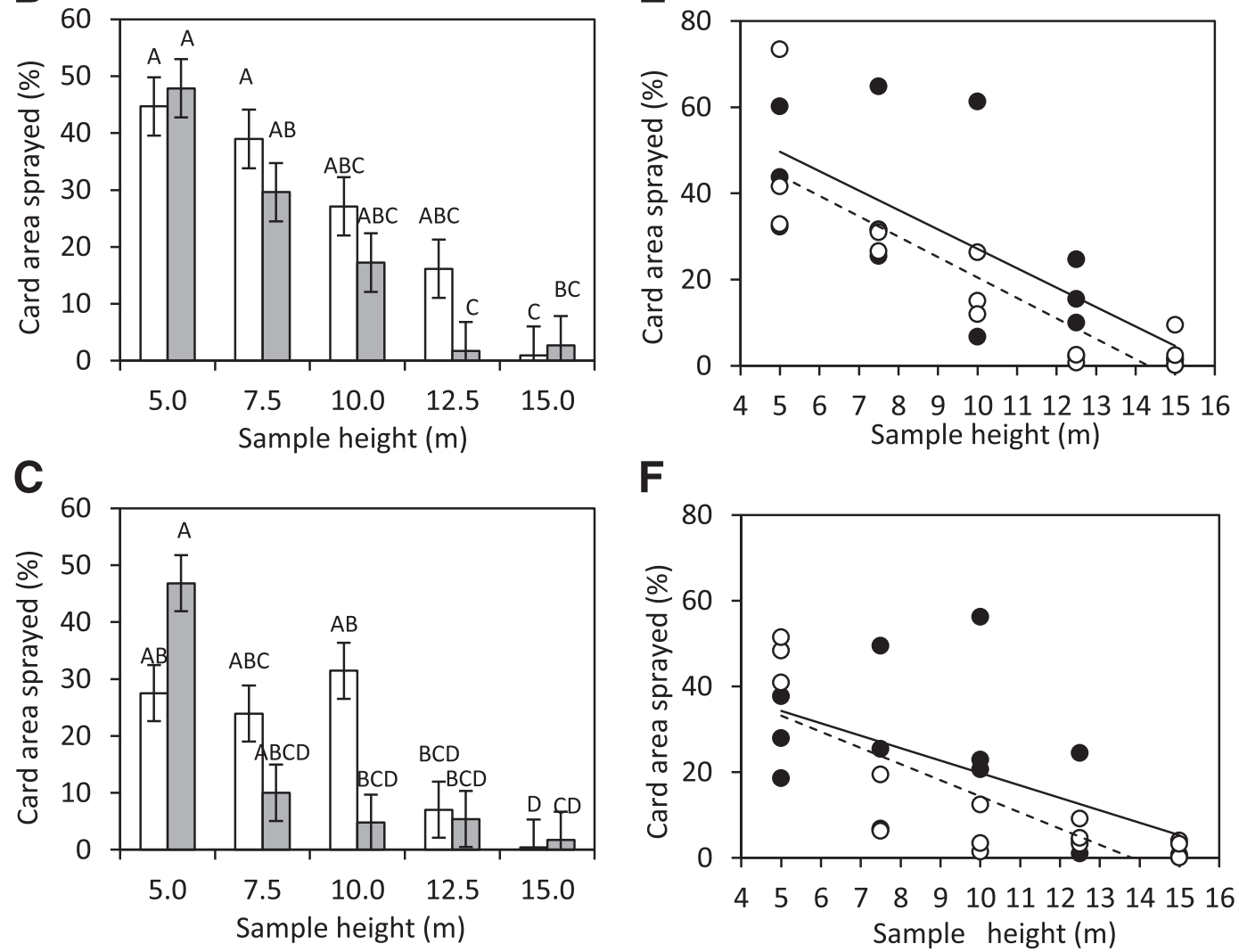

\section{$\mathbf{F}$}

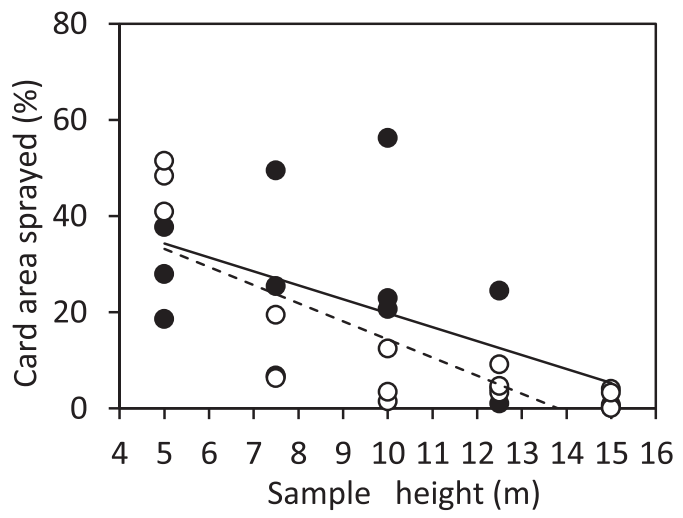

Fig. 2. A-C, Percent area covered by spray droplets collected on spray cards in three separate experiments at different heights in the canopy of mature pecan trees. Experiments: A, 28 September $2012 \mathrm{PM}$ (height $F$ value $=13.4, P$ value $<0.0001$; position $F$ value $=4.0, P$ value $=0.06$; height-position $F$ value $=0.4, P$ value $=0.8$ ); $B$, 17 October 2012 AM (height $F$ value $=17.5, P$ value $<0.0001$; position $F$ value $=2.2, P$ value $=0.2$; height-position $F$ value $=1.5, P$ value $=0.2$ ); and $\mathrm{C}, 17$ October $2012 \mathrm{PM}$ (height $F$ value $=12.7$, $P$ value $<0.0001$; position $F$ value $=1.8, P$ value $=0.2$; height-position $F$ value $=3.5, P$ value $=0.03$ ). Bars show $95 \%$ confidence intervals. Means with different letters are not significantly different based on Tukey's honestly significant difference means test. D-F, Relationship between percent area covered by spray droplets on spray cards placed at different heights in the canopy of mature pecan trees and sample height in the three separate experiments. Experiments: D, 28 September 2012 PM; E, 17 October 2012 AM; and F, 17 October 2012 PM. Spray applied using an orchard air-blast sprayer traveling at $3.22 \mathrm{~km} \mathrm{~h}^{-1}$ and 940 liters ha ${ }^{-1}$. 
Table 2. Regression analysis of the relationship between sample height in the canopy and the percent area of spray cards covered by spray droplets in three tests to compare spray coverage at different heights and positions (inner and outer canopy) in pecan trees (Trees) and sample height on strings supported by helium balloons and the percent area of spray cards covered by spray droplets in three tests to compare spray coverage at different heights and orientations (upper and lower orientation at each height) (Strings) ${ }^{\mathrm{a}}$

\begin{tabular}{clcccc}
\hline Experiment, date & Card position & $\boldsymbol{F}(\boldsymbol{P} \text { value })^{\mathbf{b}}$ & $\boldsymbol{a}$ & $\boldsymbol{b}$ & $\boldsymbol{R}^{\mathbf{2 c}}$ \\
\hline A. Trees & & & & & \\
28 September PM & Inner & $16.3(0.001)$ & 32.7 & -2.07 & 0.56 \\
& Outer & $5.3(0.04)$ & 20.2 & -1.24 & 0.29 \\
17 October AM & Inner & $14.8(0.002)$ & 72.2 & -4.51 & 0.55 \\
& Outer & $36.2(<0.0001)$ & 67.9 & -4.74 & 0.74 \\
17 October PM & Inner & $6.9(0.02)$ & 48.8 & -2.91 & 0.35 \\
& Outer & $20.3(0.0006)$ & 52.0 & -3.8 & 0.61 \\
B. Strings & & & & & \\
28 September PM & Lower & $32.7(0.002)$ & 88.2 & -4.19 & 0.77 \\
& Upper & $43.2(<0.0001)$ & 32.9 & -1.60 & 0.81 \\
17 October AM & Lower & $43.7(<0.0001)$ & 98.8 & -4.37 & 0.79 \\
& Upper & $21.6(0.0005)$ & 61.7 & -2.65 & 0.63 \\
17 October PM & Lower & $95.1(<0.0001)$ & 80.0 & -3.49 & 0.88 \\
& Upper & $21.5(0.0005)$ & 52.3 & -2.23 & 0.62 \\
\hline
\end{tabular}

${ }^{a}$ Linear regression function: $y=a+b x(a=$ intercept, $b=$ slope $)$. Spray was applied using an orchard air-blast sprayer traveling at $3.22 \mathrm{~km} \mathrm{~h}^{-1}$ and 940 liters ha ${ }^{-1}$

b $F=F$ distribution value that tests goodness of fit for the model and $P=$ probability that the $F$ value is significant.

c $R^{2}=$ coefficient of determination (proportion of variability accounted for by $X)$. collected at any height (Fig. 8A and B). Furthermore, where spray was recorded, the spray coverage was low, with a maximum of $2.12 \%$ recorded. Most other cards received no spray, or $<1 \%$ area covered. However, linear regression analysis suggested a weak effect of height and spray coverage at the locations where the cards were placed (Fig. 8C and D).

\section{Discussion}

There was a decline in the percent area covered by spray with height in pecan trees in all tests using a ground-based orchard airblast sprayer. The experiments suggested that, overall, spray coverage was statistically similar at sample height up to approximately $10 \mathrm{~m}$, above which there was significantly less coverage. These results are comparable with (but not identical to) results from previous studies (Bock et al. 2013; Reilly et al. 2007; Sumner 2004). In those studies, declines with tree height were also observed, but only the Bock et al. study compared coverage at different heights; and, in that study, statistically less coverage was observed at $10 \mathrm{~m}$ and higher compared with lower sample heights. Thus, there is significantly less coverage from orchard sprayers above heights of approximately $10 \mathrm{~m}$ in tree canopies. The data from the cards on platforms supported by helium-filled balloons suggested that the quantity of spray collected was a little higher at 10 and $15 \mathrm{~m}$ but still declined to very low coverage at 20 to $25 \mathrm{~m}$. In comparison with smaller orchard crops (Banaj et al. 2010; Pergher and Gubiani 1997), the decline in coverage with sample height that we documented is more profound.

In these studies, the relationship between spray coverage and sample height was defined by linear regression, describing the decline in coverage. In trees, the regression tended to intersect the $\mathrm{x}$-axis at 15 to $20 \mathrm{~m}$, suggesting that little spray reached heights $>15 \mathrm{~m}$. For the spray cards attached to platforms on strings supported by helium-filled

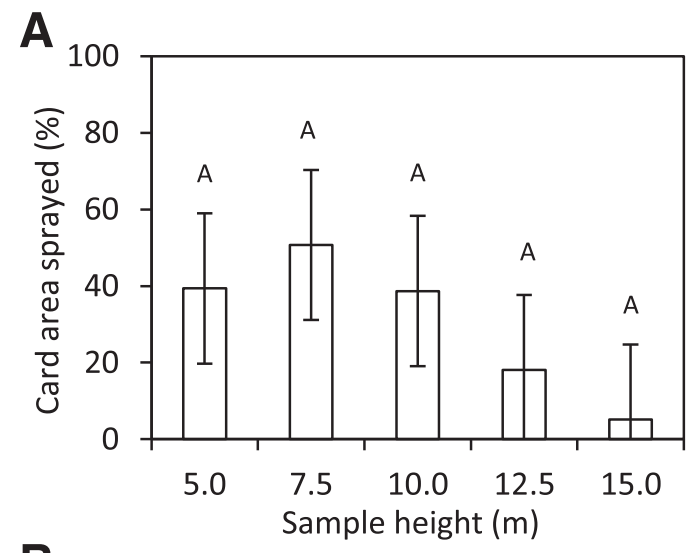

B
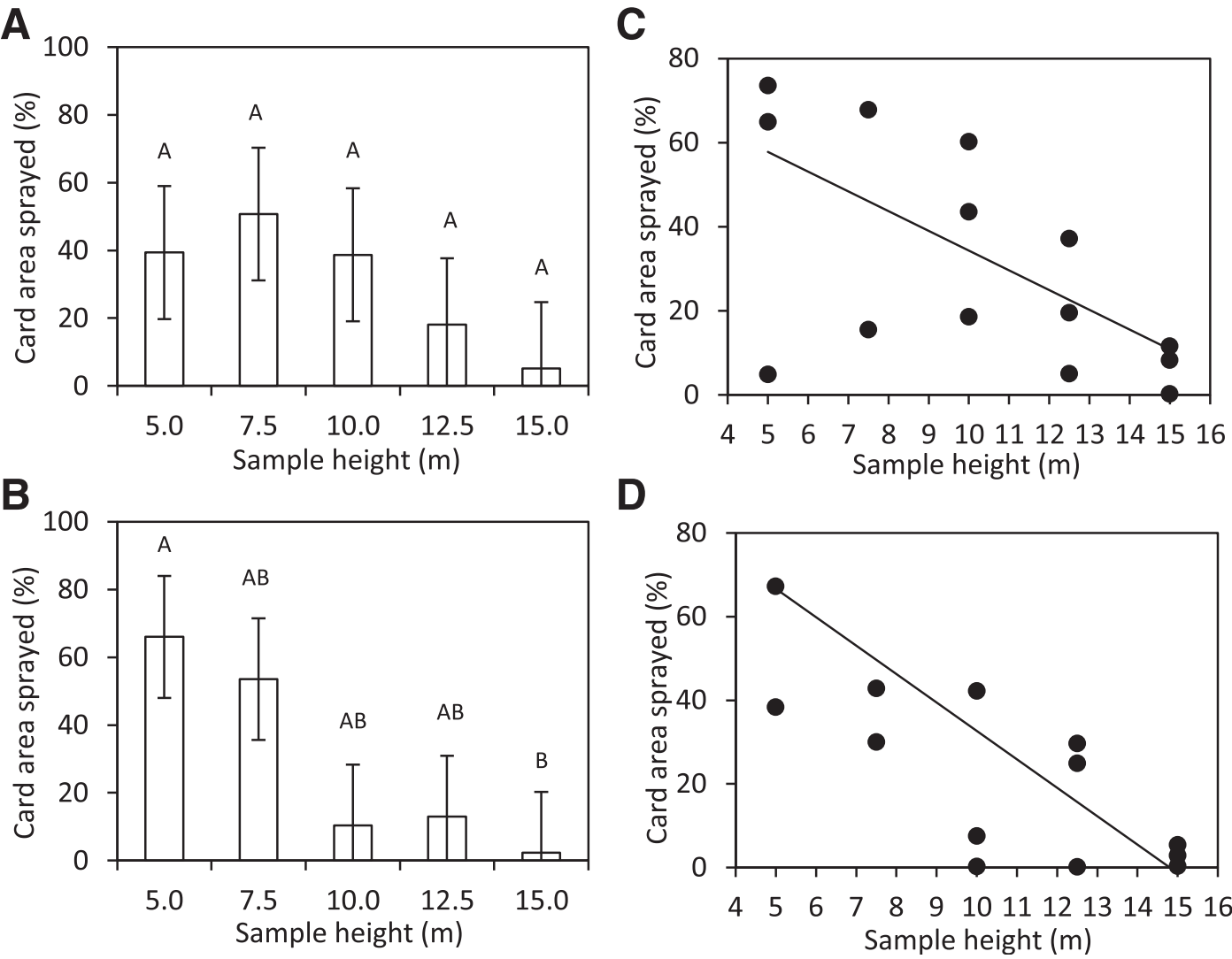

D

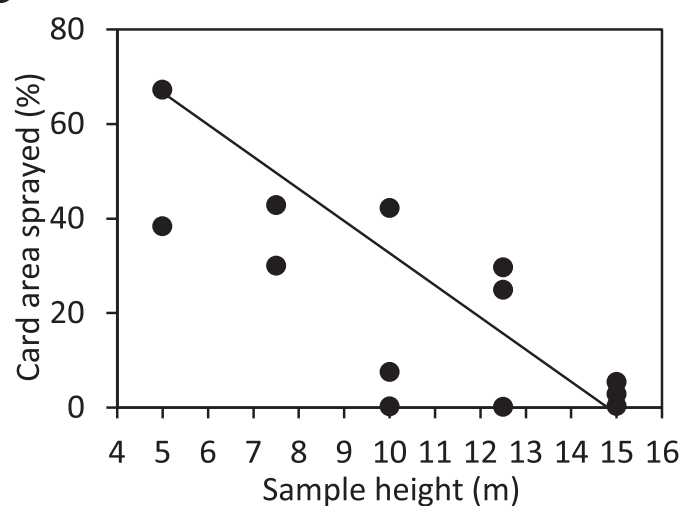

Fig. 3. A and B, Percent area covered by spray droplets collected on spray cards in two experiments at different heights in the canopy of mature pecan trees when the trees have no leaves: A, 10 April $2013 \mathrm{AM}$ (height $F$ value $=2.0, P$ value $=0.2$ ) and $\mathrm{B}, 10$ April $2013 \mathrm{PM}$ (height $F$ value $=4.4, P$ value $=0.03$ ). Bars show $95 \%$ confidence intervals. Means with different letters are not significantly different based on Tukey's honestly significant difference means test. $\mathbf{C}$ and $\mathbf{D}$, Linear regression analysis $(y=a+b x$, where $a=$ intercept and $b=$ slope) showing the relationship between percent area covered by spray droplets on spray cards placed at different heights in the canopy of mature pecan trees and sample height in the two experiments when the trees had no leaves: $\mathrm{C}, 10 \mathrm{April} 2013 \mathrm{AM}\left(F\right.$ value $=7.1, P$ value $\left.=0.02, a=81.3, b=-4.70, R^{2}=0.35\right)$ and $\mathrm{D}, 10 \mathrm{April} 2013 \mathrm{PM}(F$ value $=$ $15.9, P$ value $\left.=0.002, a=100.7, b=-6.80, R^{2}=0.55\right)$. Spray applied using an orchard air-blast sprayer traveling at $3.22 \mathrm{~km} \mathrm{~h}^{-1}$ and 940 liters ha ${ }^{-1}$. 
balloons, the tendency was for the regression solutions to intersect the $\mathrm{x}$-axis between 20 and $25 \mathrm{~m}$. The foliage and branches in the canopy of a tree likely impede spray coverage, thus reducing efficacy. The variability in card coverage in tree canopies observed in this study and noted elsewhere (Fox et al. 2008) also confirms that different spray card positions affect the coverage due to aspect, orientation, and screening by leaves or branches. Canopy density affects spray coverage (Travis et al. 1987b), and the differences we observed between the spray coverage on platforms and the height at which spray was collected is most likely a result of the canopy impeding vertical movement of the wind and spray. Although orientation had a major effect on coverage (and the platforms were relatively stable compared with cards stapled to leaves), the difference in height at which spray was sampled appeared to be at most a few meters (whereas there was $<10 \%$ spray coverage at $\geq 15 \mathrm{~m}$ in the canopy, on the platforms supported by helium-filled balloons, similarly low coverage was at $>20 \mathrm{~m}$ ). Variability in spray coverage does have ramifications for control of scab in the canopies of different trees in an orchard, with coverage being influenced by foliage position and density, branches, and possibly other environmental factors. Not all parts of all trees will receive equally uniform coverage.

Wind speed declined rapidly with distance from the air-blast volute, which confirms previous observations of wind speed and height (or distance) from an axial air-blast fan (Randall 1971). As previously noted, the air jets carry the spray into the canopy (Fox et al. 2008). The larger droplets are deposited by inertial impaction and sedimentation, while smaller droplets are entrained in the air and deposit when they are carried close to a target in the turbulence. We did
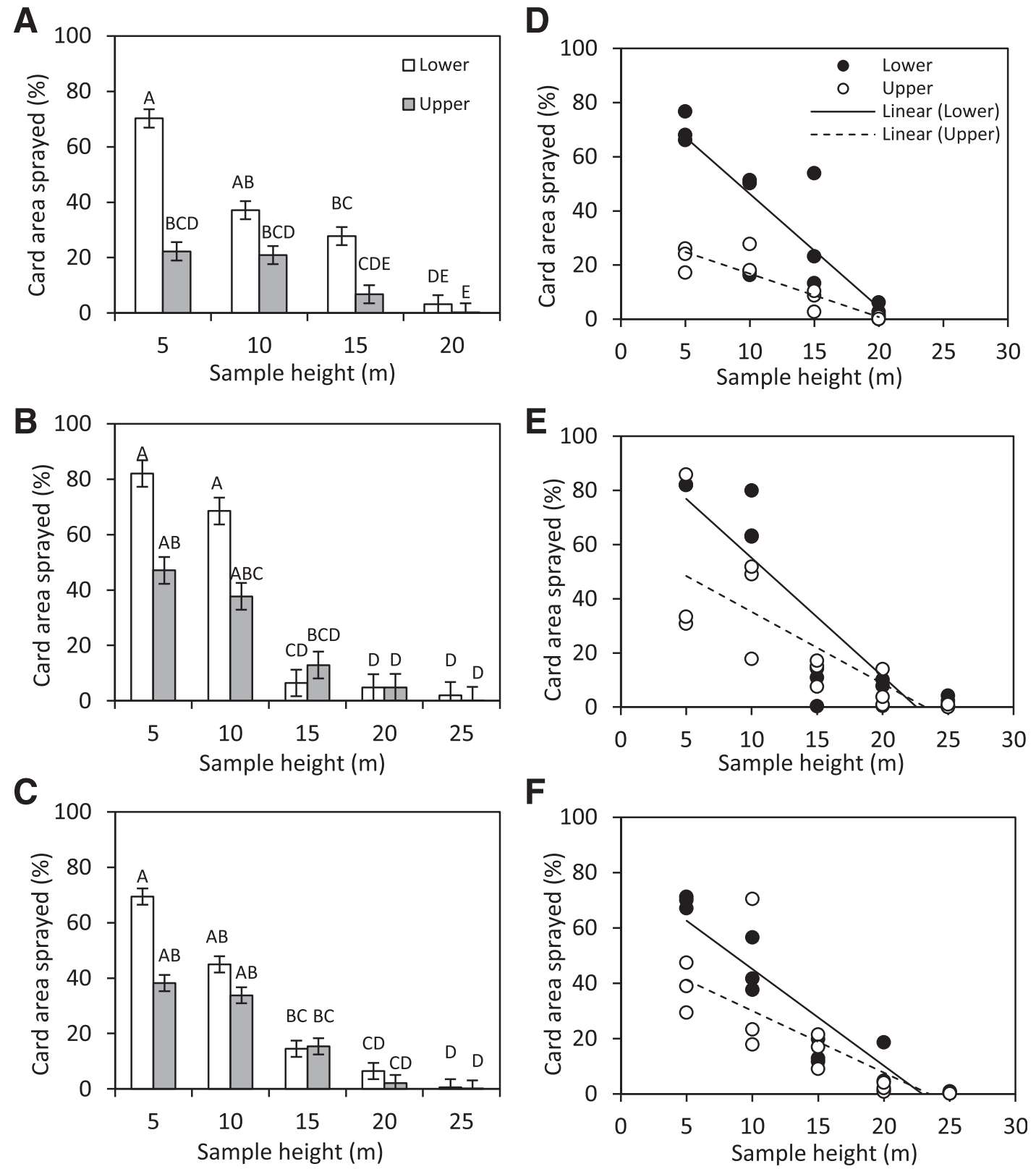

Fig. 4. A-C, Percent area covered by spray droplets collected on spray cards in three separate experiments at different heights on platforms attached to strings supported by helium-filled balloons: A, 28 September $2012 \mathrm{PM}$ (height $F$ value $=29.7, P$ value $<0.0001$; position $F$ value $=28.8, P$ value $<0.0001$; height-position $F$ value $=1.6$, $P$ value $=0.02$ ); $\mathrm{B}, 17$ October $2012 \mathrm{AM}$ (height $F$ value $=33.1, P$ value $<0.0001$; , position $F$ value $=3.1, P$ value $=0.09$; height-position $F$ value $=1.7, P$ value $=0.2$ ); C, 17 October $2012 \mathrm{PM}$ (height $F$ value $=46.5, P$ value $<0.0001$; position $F$ value $=5.7, P$ value $=0.03$; height-position $F$ value $=1.1, P$ value $=0.4$ ). Bars show 95\% confidence intervals. Means with different letters are not significantly different based on Tukey's honestly significant difference means test. D-F, Relationship between percent area covered by spray droplets on spray cards placed at different heights on platforms attached to strings supported by helium-filled balloons and sample height in the three separate experiments: D, 28 September 2012 PM; E, 17 October 2012 AM; and F, 17 October 2012 PM. Spray applied using an orchard air-blast sprayer traveling at $3.22 \mathrm{~km} \mathrm{~h}^{-1}$ and 940 liters ha ${ }^{-1}$. 
not study droplet size in this series of experiments due to excessive coalescence of droplets at low sample heights but it is clear that greater coverage occurs lower in the canopy, most likely due to the velocity of the air flow and the increasingly diffuse spray as it billows
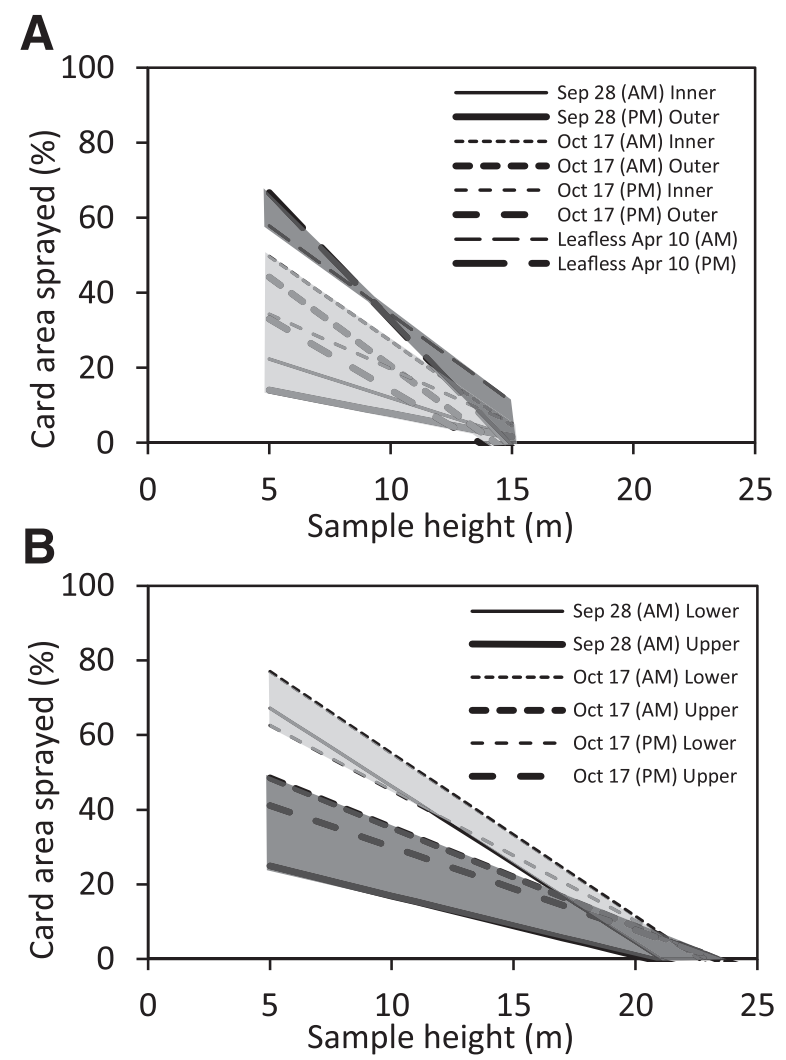

Fig. 5. Overall spray coverage based on the combined regression solutions from separate experiments. A, Trees with or without foliage. Pale gray-shaded area showing range in coverage based on combined regression solutions for cards placed in the inner and outer canopy of trees with foliage, and dark gray-shaded area showing range in coverage on combined regression solutions for cards placed in trees with no foliage. B, Platforms, with pale gray-shaded area showing coverage on lower most facing cards and dark gray-shaded area showing coverage on upper most facing cards. into an ever greater volume of air. As has been observed previously (Cunha et al. 2012; Salyani and Fox 1999), there are limitations in estimating droplet numbers or sizes on spray cards. We found that, when approximately $20 \%$ of the card area is covered, separation of droplets became increasingly difficult, resulting in underestimation of spray deposited if using droplet counts.

Aerial application provides an alternative to ground-based airblast sprays but these low-volume applications (74 to 94 liters ha ${ }^{-1}$ ) potentially affect the percent area covered. Furthermore, spray falling from the sky mostly strikes the upper side of exposed foliage. We did not perform a thorough test of aerial application in the upper foliage of the tall trees where the experiment was tested $(24 \mathrm{~m})$; however, the results from placing cards in the canopy at heights up to $20 \mathrm{~m}$ suggested relatively low coverage ( 0 to $<3 \%$ on all cards). However, intensive aerial application (i.e., multiple applications: four or more during fruit development, depending on weather conditions) is reported to reduce severity of pecan scab in the canopy (particularly in the upper canopy) of pecan trees (Bertrand and Brenneman 2001). However, most growers that use an aerial sprayer service generally do not apply more than two to three aerial sprays per season. The effect of such a reduced aerial spray regime has not been quantified, and the characteristics of aerial applications have been only partially characterized using metallic tracers (Reilly et al. 2007). An understanding of droplet size, number, coverage, and distribution at different locations in the canopy will be invaluable in improving our understanding of aerial application in relation to disease control in pecan trees.

The weather conditions during these experiments were reasonably constant (Table 1). According to the Environmental Protection Agency (EPA), spray application in orchards should generally be avoided at wind speeds $>1.3$ to $4.5 \mathrm{~m} \mathrm{~s}^{-2}$ (Mulkey 2014). When we applied sprays in these experiments, wind speed did not exceed the range stipulated by the EPA. Thus, any impact of wind affecting spray coverage should be considered slight.

The proportion of spray lost to drift or onto the ground has not been investigated in pecan orchards but is an important component to consider for improving efficiency of application and minimizing environmental impacts (Fox et al. 2008). The loss in pecan orchards remains to be established: how much spray settles to the orchard floor and is lost to drift. Furthermore, the effects of application volume and tractor speed have not been fully characterized for these large orchard sprayers in a tall tree crop such as pecan. The relationship between the gradient in fungicide and disease severity (or insect pest pressure)
A

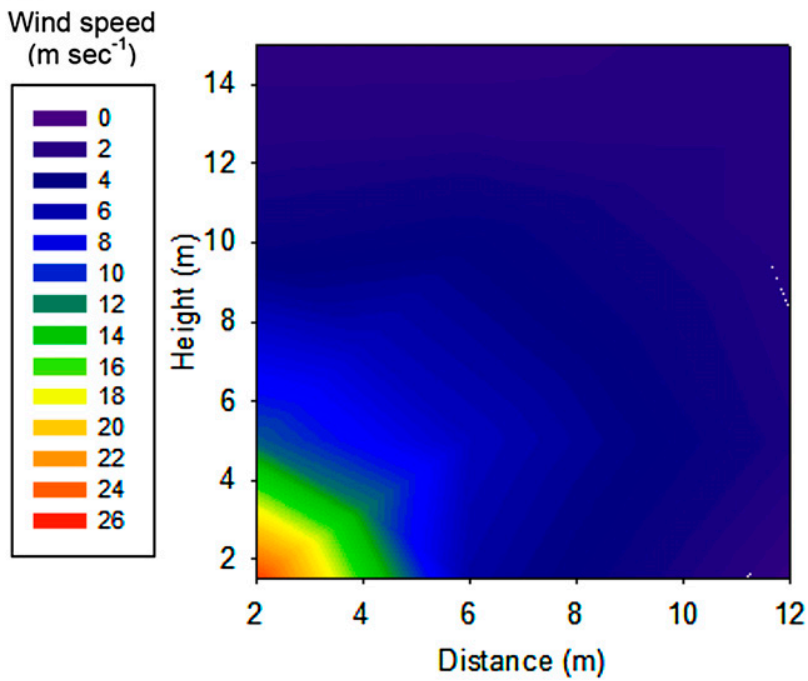

B

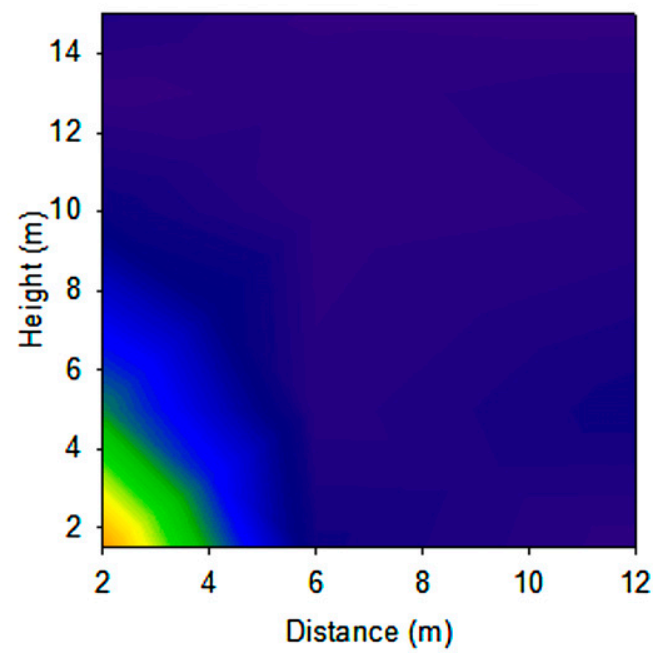

Fig. 6. Wind speeds measured at different distances and heights from an orchard air-blast sprayer fan exit aperture in two experiments: A, 20 November 2012 and B, 26 November 2012. Speed measured at $40 \mathrm{~cm}$ from exit $=37 \mathrm{~m} \mathrm{~s}^{-1}$. 
has been only partially characterized (Bock et al. 2013). Only by obtaining data on the current systems and developing new methods of spray application or tree management will improvements be made in disease control.
Large air-blast orchard sprayers are the primary tools available for managing disease and pests in tall tree crops such as pecan, and appear to do an excellent job to at least a height of $10 \mathrm{~m}$. Considering the inertia of still air they have to push against and the barrier of the
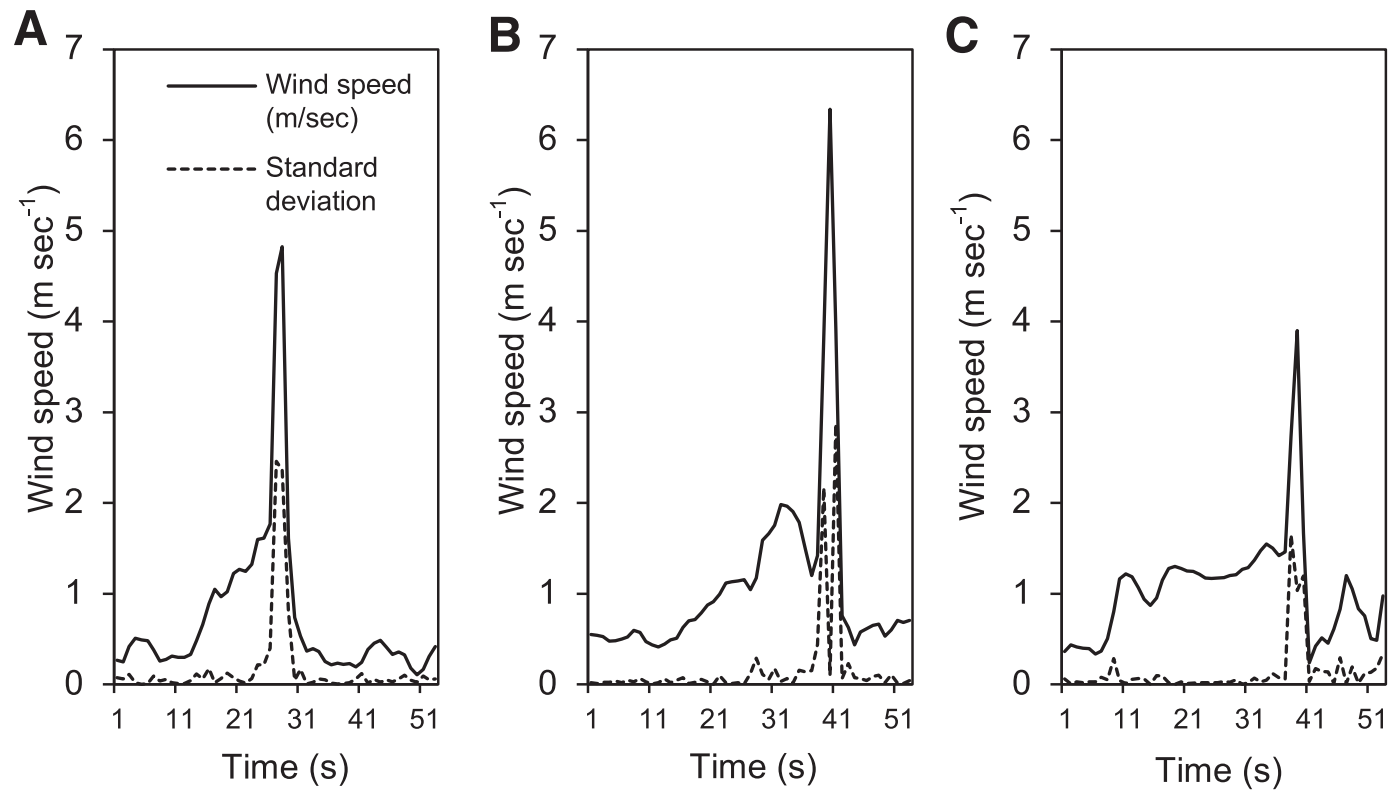

Fig. 7. Number of seconds the mean wind speed $\left(\mathrm{m} \mathrm{s}^{-1}\right)$ is elevated when an air-blast sprayer traveling at $3.22 \mathrm{kph}(2 \mathrm{mph})$ passes a tree, as recorded at $6 \mathrm{~m}$ horizontal distance and 3 $\mathrm{m}$ vertical distance from an orchard air-blast sprayer fan. Results A-C show the three consecutive times the experiment was performed between 4 and 5 PM on 26 November 2012 .
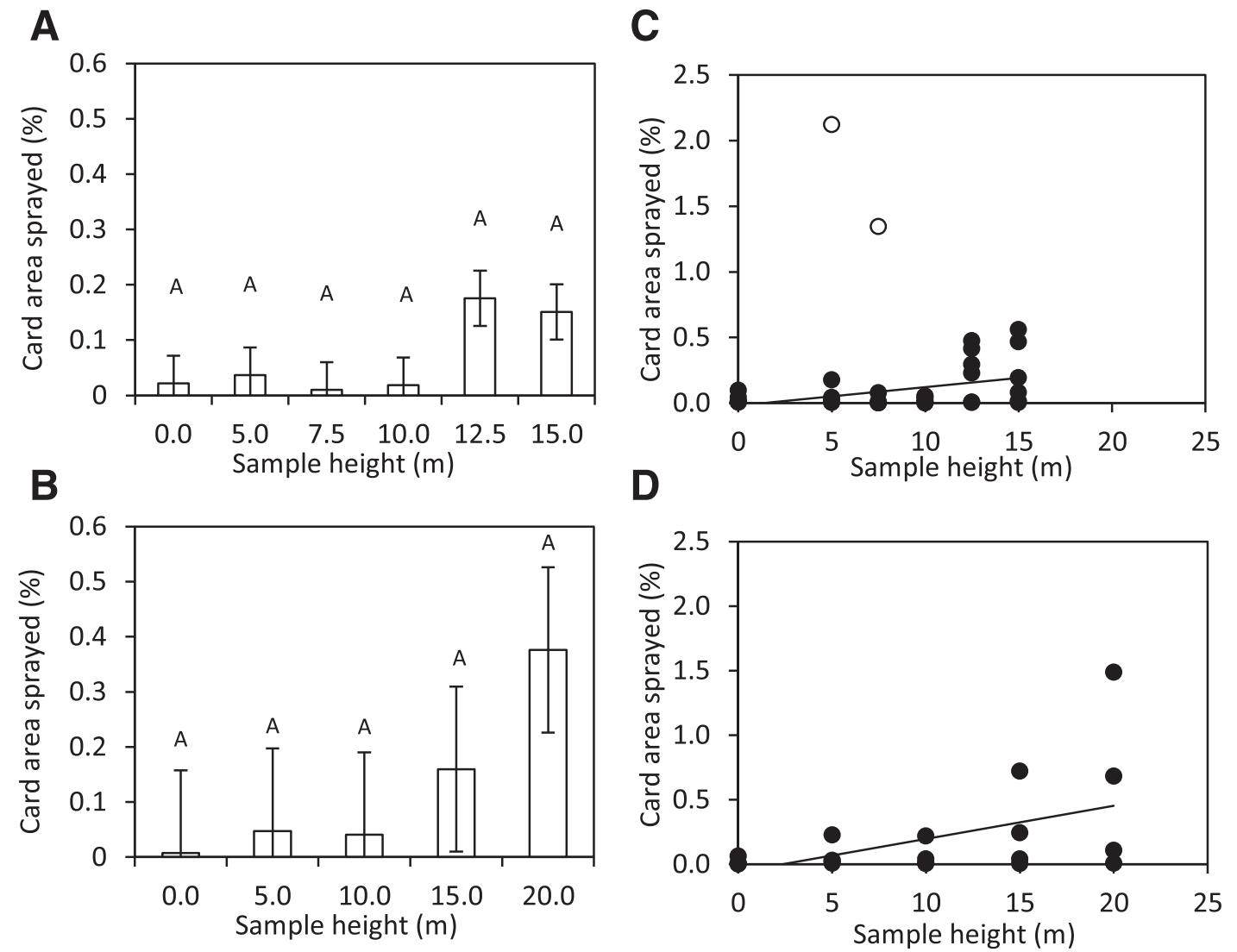

Fig. 8. A and B, Percent area covered by spray droplets collected on spray cards in two separate experiments at different heights in the canopy of mature, 24-m-tall pecan trees: A, 21 June 2012 (height $F$ value $=3.1, P$ value $=0.02$ ) and $\mathbf{B}$, (height $F$ value $=1.9, P$ value $=0.2$ ). For the data from 21 June 2012, two outliers were not included in the analysis (see text). Bars show $95 \%$ confidence intervals. Means with different letters are not significantly different based on Tukey's honestly significant difference means test. $\mathbf{C}$ and $\mathbf{D}$, Linear regression analysis $(y=a+b x$, where $a=$ intercept and $b=$ slope) showing the relationship between percent area covered by spray droplets on spray cards placed at different heights in the canopy of mature pecan trees and sample height in two experiments: $C, 21$ June 2012 ( $F$ value $=8.4, P$ value $=0.007, a=-0.02, b=0.014, R^{2}=0.21$ ) and $D,\left(F\right.$ value $=6.1, P$ value $\left.=0.02, a=-0.06, b=0.009, R^{2}=0.25\right)$. For the data from 21 June 2012 , two outliers (indicated as open circles) were not included in the regression analysis (see text). Spray applied using an airplane sprayer at 74 to 94 liters ha ${ }^{-1}$ 
canopy, they are able to project the spray into the canopy to at least $10 \mathrm{~m}$ or more. However, commercial orchards of pecan often have older trees with heights of at least 20 to $25 \mathrm{~m}$. Furthermore, although the majority of fruit might be born in the middle $50 \%$ stratum of a tree (Lozano-Gonzalez et al. 1992), in crowded orchard situations, most of the canopy and nut production is forced higher and, thus, beyond where efficacious spray coverage can reach. Extended volutes attached to the sprayer might help attain greater efficacy higher in the tree; this also needs to be explored.

Further research will improve our understanding of spray coverages and the limits imposed by existing technology and tree management. Alternative management practices such as hedging (Wood and Stahmann 2004), which reduces tree height, provides another approach to ensuring more efficacious fungicide coverage. No dwarfing root stocks are currently available for pecan. Aerial application, although helpful, might not provide an alternative, and applying both aerial and ground sprays throughout the season might not be cost effective.

\section{Acknowledgments}

We thank the Georgia Commodity Commission for Pecans in providing some financial support towards these studies, and W. Evans and T. Endalew for assistance with experiments and image analysis.

\section{Literature Cited}

Banaj, D., Tadic, V., Lukinac, J., and Horvat, D. 2010. The use of water sensitive paper for the evaluation of spray coverage in an apple orchard. Poljoprivreda 16: 43-49.

Bertrand, P. F., and Brenneman, T. B. 2001. Aerial and weather based fungicide application for pecan scab control. Pages 62-69 in: Proc. 94th South East Pecan Growers Assoc. Conv. Perdido Beach Resort, Orange Beach, AL.

Bock, C. H. 2013. Fusicladium effusum. In: Crop Protection Compendium. CAB International, Wallingford, UK. http://www.cabi.org/isc/datasheet/13719

Bock, C. H., Cottrell, T. E., Hotchkiss, M. W., and Wood, B. W. 2013. Vertical distribution of scab in large pecan trees. Plant Dis. 97:626-634.

Brenneman, T. B., Brock, J., Culpepper, A. S., Hudson, W., Wells, L., and Mitchem, W. 2014. Commercial Pecan Spray Guide. University of Georgia Extension. http://www.caes.uga.edu/commodities/fruits/pecan/documents/2014-PecanSpray-Guide.pdf

Celen, I. H., Arin, S., and Durgut, M. R. 2008. The effect of the air blast sprayer speed on the chemical distribution in vineyard. Pak. J. Biol. Sci. 11:1472-1476.

Cunha, M., Carvalho, C., and Marcal, A. R. S. 2012. Assessing the ability of image analysis processing software to analyse spray quality on water sensitive papers used as artificial targets. Biosyst. Eng. 111:11-23.

Demaree, J. B. 1924. Pecan scab with special reference to sources of the early spring infections. J. Agric. Res. 38:321-333

Fox, R. D., Brazee, R. D., Svensson, S. A., and Reichard, D. L. 1992. Air jet velocities from a cross-flow fan sprayer. Trans. ASABE 35, 5:1381-1384.

Fox, R. D., Derksen, R. C., Krause, C. R., Cooper, J. A., and Ozkan, H. E. 2003. Visual and image system measurement of spray deposits using water-sensitive paper. Appl. Eng. Agric. 19, 5:549-552.

Fox, R. D., Derksen, R. C., Zhu, H., Brazee, R. D., and Svensson, S. A. 2008. A history of air-blast sprayer development and future prospects. Trans. ASABE. $51,2: 405-410$

Gil, E., Landers, A., Gallart, M., and Llorens, J. 2013. Development of two portable patternators to improve drift control and operator training in the operation of vineyard sprayers. Span. J. Agric. Res. 11, 3:615-625.

Gottwald, T. R. 1982. Spore discharge by the pecan scab pathogen Cladosporium caryigenum. Phytopathology 72:1193-1197.

Gottwald, T. R. 1985. Influence of temperature, leaf wetness period, leaf age, and spore concentration on infection of pecan leaves by conidia of Cladosporium caryigenum. Phytopathology 75:190-194.

Gottwald, T. R., and Bertrand, P. F. 1982. Patterns of diurnal and seasonal airborne spore concentrations of Fusicladium effusum and its impact on a pecan scab epidemic. Phytopathology 72:330-335.

Gottwald, T. R., and Bertrand, P. F. 1983. Effect of time of inoculation with Cladosporium caryigenum on pecan scab development and nut quality. Phytopathology 73:714-718.

Gottwald, T. R., and Bertrand, P. F. 1988. Effects of an abbreviated pecan disease control program on pecan scab disease increase and crop yield. Plant Dis. 72:27-32.

Herrington, P. J., Mapother, H. R., and Stringer, A. 1981. Spray retention and distribution on apple trees. Pestic. Sci. 12, 5:515-520.
Hipkins, P., and Grisso, R. 2009. Droplet chart/selection guide. Va. Coop. Ext. Publ. 442-031.

Holownicki, R., Doruchowski, G., Godyn, A., and Swiechowski, W. 2000 Variation of spray deposit and loss with air-jet directions applied in orchards. J. Agric. Eng. Res. 77, 2:129-136.

Isakeit, T. 2009. Pecan scab: Understanding fungicide activity to prevent fungicide resistance http://pecan.ipmpipe.org/library/content/pecan_scabMH\%20edited_management1. pdf

Lamari, L. 2002. ASSESS: Image Analysis Software for Plant Disease Quantification. American Phytopathological Society, St. Paul, MN.

Latham, A. J. 1982. Effects of some weather factors and Fusicladium effusum conidium dispersal on pecan scab occurrence. Phytopathology 72:1339-1345.

Lozano-Gonzalez, R., Storey, J. B., and Harris, M. K. 1992. Three-dimensional characterization of bearing pecan tree. HortScience 27:1181-1183.

Mulkey, M. E. 2014. Pesticides: Regulating pesticides: Pesticide registration (PR) Spray and dust drift label statements for pesticide products. Pesticide registration (PR) notice 2001-X. www.epa.gov/PR Notices/prdraft-spraydrift801.htm

Olson, B., Krueger, B., and Teviotdale, B. 1984. Helicopter vs. air blast sprayer for walnut blight control. Pages 163-165 in: Calif. Walnut Marketing Board Walnut Res. Conf. Walnut Res. Rep. 1984. Online publication. http://walnutresearch ucdavis.edu/1984/1984_163.pdf

Panneton, B. 2002. Image analysis of water sensitive cards for spray coverage experiments. Appl. Eng. Agric. 18:179-182.

Pergher, G. 2004. Field evaluation of a calibration method for air-assisted sprayers involving the use of a vertical patternator. Crop Prot. 23:437-446.

Pergher, G., and Gubiani, R. 1997. A comparison of methods for assessing vertical spray distributions from air-assisted sprayers. EPPO Bull. 27:227-234.

Randall, J. M. 1971. The relationships between air volume and pressure on spray distribution in fruit trees. J. Agric. Eng. Res. 16, 1:1-31.

Reilly, C. C., Wood, B. W., Cottrell, T. E., Sumner, P., Wells, L., and Funderburk, F. 2007. Comparison of ground and aerial application, fungicide deposition and biological activity in large pecan trees. Pages 115-122 in: Proc. Southeastern Pecan Growers Assoc. 100th Annu. Conv. Marriot Bay Point Resort, Panama City Beach, FL

Reynolds, K. L., Brenneman, T. B., and Betrand, P. F. 1997. Sensitivity of Cladosporium caryigenum to propiconazole and fenbuconazole. Plant Dis. 81:163-166.

Salyani, M., and Fox, R. D. 1999. Evaluation of spray quality by oil and water sensitive papers. Trans. ASABE 42:37-43.

Salyani, M., and Hoffmann, W. C. 1996. Air and spray distribution from an aircarrier sprayer. Appl. Eng. Agric. 12:539-545.

Salyani, M., Sweeb, R. D., and Farooq, M. 2006. Comparison of string and ribbon samplers in orchard spray applications. Trans. ASABE 49, 6:1705-1710.

Salyani, M., Zhu, H., Sweeb, R. D., and Pai, N. 2013. Assessment of spray distribution with water-sensitive paper. Agric. Eng. Int. CIGR J. 15, 2:101-111

Sanderlin, R. S. 1995. Effect of nut scab on pecan yield and quality components. Pages 45-49 in: Sustaining Pecan Productivity into the 21st Century: Second Natl. Pecan Workshop Proc. Wagoner, OK. U.S. Dep. Agric. Agric. Res. Serv.

Stevenson, K. L. 1999. Fungicide resistance management in pecans. Pages 58-64 in: Proc. of the 92nd Southeast. Pecan Growers Assoc., Asheville, NC, March 14-16, 1999.

Stevenson, K. L., and Bertrand, P. F. 2001. Within-season dynamics of yield loss due to pecan scab fruit infections. (Abstr.) Phytopathology 91:S85.

Stevenson, K. L., Bertrand, P. F., and Brenneman, T. B. 2004. Evidence for reduced sensitivity to propiconazole in the pecan scab fungus in Georgia (Abstr.) Phytopathology 94:S99.

Sumner, P. E. 2004. Experiences with pecan air blast sprayers. Presented at The 2004 American Society of Agricultural Engineers/Canadian Society of Agricultural Engineers Annual International Meeting, Fairmont Chateau Laurier, The Westin, Government Centre, Ottawa, Ontario, Canada.

Sumner, P. E. 2005. Pecan orchard air blast sprayers. Online publication. http:// www.caes.uga.edu/commodities/fruits/pecan/growers/documents/pecan \% 20orchard\%20sprayers.pdf

Syngenta. 2002. Water-sensitive paper for monitoring spray distributions. Publ. TN08-223. Syngenta Crop Protection AG, Basel.

Travis, J. W., Skroch, W. A., and Sutton, T. B. 1987a. Effects of travel speed, application volume, and nozzle arrangement on deposition of pesticides in apple trees. Plant Dis. 71, 7:606-612.

Travis, J. W., Skroch, W. A., and Sutton, T. B. 1987b. Effect of canopy density on pesticide deposition and distribution in apple trees. Plant Dis. 71, 7:613-615.

Turechek, W. W., and Stevenson, K. L. 1998. Effects of host resistance, temperature, leaf wetness, and leaf age on infection and lesion development of pecan scab. Phytopathology 88:1294-1301.

Wells, L., ed. 2007. Cultural management of commercial pecan orchards. Southeast. Pecan Grow. Handb. Univ. Ga. Coop. Ext. Ser. Bull. 1327.

Wood, B. W., and Stahmann, D. 2004. Hedge pruning pecan. HortTechnology 14:63-72. 